\title{
Yeni Mezun Sosyal Çalışmacıların “İşsizlik” Kavramına İlişkin Metaforik Algılarının İncelenmesi
}

\author{
Gamze İSMAİLOĞLU ${ }^{1}$ ve Ali Fuat ERSOY ${ }^{2}$
}

Öz

Günümüzde en büyük sorunlardan biri işsizliktir. İsssizlik sorunundan en çok etkilenen gruplardan biri ise sayıları her yıl artan sosyal hizmet lisans bölümü mezunlarıdır. Bu araştırmanın amacı, yeni mezun sosyal çalışmacıların işsizlik kavramına yönelik ifade ettikleri metaforları incelemektir. Araştırmada nitel araştırma modellerinden biri olan fenomenoloji (olgu bilim deseni) kullanılmıştır. Araştırmanın çalışma grubunu, farklı üniversitelerin sosyal hizmet bölümünden 2018-2019 ve 2019-2020 eğitim ve öğretim yıllarında mezun olmuş 80 sosyal çalışmacı oluşturmaktadır. Araştırma verileri yeni mezun sosyal çalışmacıların "İşsizlik...... gibidir; Çünkü ......" cümlelerini tamamlamaları ile elde edilmiştir. Araştırma verileri içerik analizi yöntemi kullanılarak analiz edilmiştir. Araştırma sonunda, yeni mezun sosyal çalışmacıların işsizlik kavramıyla ilgili toplam 58 metafor belirttikleri görülmüştür. Katılımcıların işsizlik kavramılla ilgili "Doğal Afet/Oluşum" (f=16), "Duygu Yansıması" (f=16), "Mekan Tasviri” (f=14), "Dezavantaj Durumu" (f=13), "İşlev Bozukluğu Yaratan Durum" (f=12) ve "Nesne” (f=9) olmak üzere toplam 6 farklı kategoride toplanabilecek metafor üretmişlerdir. Belirlenen sonuçlara göre, yeni mezun sosyal çalışmacılar işsizlik kavramına ilişkin oldukça olumsuz ve umutsuz görüşlere sahiptir. Bu kapsamda, sosyal hizmet mesleğinin ülkemizde istihdam olanaklarının artırılması ve işsizlik sürecinde olan özellikle yeni mezun bireylere ilişkin uygulamalar geliştirilmesi önerilmektedir.

Anahtar Kelimeler: Sosyal Çalışmacılar, İşsizlik, Metafor

\section{Investigating the Metaphoric Perceptions of Recently Graduated Social Workers'} Towards the Concept of Unemployment

\begin{abstract}
Unemployment is one of the biggest problems of today's Turkey. In the report "Labor Force Status of University Graduates", published by TUIK in 2018, it is seen that graduates of social work programs are the most affected group by this problem $(24.3 \%$ unemployment rate). The purpose of this study is to examine the metaphors of recently graduated social workers regarding the concept of unemployment. Phenomenology, one of the qualitative research models, was used in the research. The working group of the research consists of 80 social workers who graduated from the social work departments of different universities in 2018-2019 and 2019-2020 academic years. Research data was obtained by completing this sentence: "Unemployment is like/as ...... because ......". The research data were analyzed using the content analysis method. At the end of the study, it was seen that recently graduated social workers stated 58 metaphors about the concept of unemployment. They produced metaphors that can be grouped into 7 different categories as "Reflection of Emotional" ( $f=16)$, "Natural Disaster/Occurrence" $(\mathrm{f}=16)$, "Disadvantage Situation" ( $\mathrm{f}=15)$, "Description of Space" ( $\mathrm{f}=13)$, " Dysfunction Causing Situation" ( $\mathrm{f}=12$ ) and "Object" ( $\mathrm{f}=8)$. According to determine the results, recently graduated social workers have very negative and hopeless views about unemployment. In this context, it is recommended to increase the employment opportunities in our country for the social work profession and to develop practices especially for new graduates who are in the process of unemployment.
\end{abstract}

Key Words: Social Workers, Unemployment, Metaphor

\section{Atıf İçin / Please Cite As:}

İsmailoğlu, G. ve Ersoy, A. F. (2021). Yeni mezun sosyal çalışmacıların “işsizlik” kavramına ilişkin metaforik algilarının incelenmesi. Manas Sosyal Arastırmalar Dergisi, 10(4), 2459-2472.

Geliş Tarihi / Received Date: 29.12.2020

Kabul Tarihi / Accepted Date: 26.06.2021

\footnotetext{
1 Yüksek Lisans Öğrencisi - Karabük Üniversitesi Lisansüstü Eğitim Enstitüsü Sosyal Hizmet ABD, 2028240002@ogrenci.karabuk.edu.tr,

(iD) ORCID: 0000-0003-2853-2175

2 Prof. Dr. - Karabük Üniversitesi İktisadi ve İdari Bilimler Fakültesi Sosyal Hizmet Bölümü, alifuatersoy@karabuk.edu.tr 


\section{Giriş}

Uluslararası Çalışma Örgütü’nün tanımına göre işsizlik oranı bir ekonominin, çalışmak için müsait olmalarına ve aktif olarak iş aramalarına rağmen çalışamayan kişiler için istihdam yaratma konusundaki yetersizliğini yansıtmaktadır. Son yüzyllarda yaşanan yapısal değişimlerin yol açtı̆̆ işsizlik, geliştirilen sosyal ve ekonomik politikalara rağmen toplumun her düzeyinde büyük dezavantajlar oluşturan bir gerçektir (Nalinci ve Yapıc1, 2020, s. 483). İşsizlik, gelişmekte olan ülkelerde daha çok gündem yaratmasına rağmen, gelişmiş ekonomilere sahip ülkelerin de tamamen kurtulamadığı bir sosyal sorundur (Iş̧1k, 2016, s. 132). Dolayısıyla gelişmekte olan ülkeler arasında yer alan Türkiye'nin de karşı karşıya olduğu en kritik kalkınma sorunlarından biri genç işsizliğidir. İşsizlik son sürat global bir sorun olma noktasına gelirken, bu sorunun büyük bir kısmını oluşturanların üniversite mezunu gençler olması, mikro düzeyde ayr1 sorunlara sebebiyet vermektedir.

Üretimin temel olarak bilgi ve bilim ile gerçekleştirildiği, 1980'li y1llardan günümüze kadar hâkim olan toplumsal düzen "enformasyon çağı" olarak adlandırlmaktadır (İrge, 2012, s. 65). Enformasyon çağı bilgi ve bilimi ön planda tuttuğu ve "nitelikli işgücü" kavramını ortaya çıkardığı için yapısal olarak yarattı̆̆1 değişimlerden en önemlisi, eğitime verilen önemin artarak yaygınlaştırllmasıdır. Bu doğrultuda son yıllarda yükseköğrenim ve lisansüstü eğitimlerine olan ilginin ve bu eğitimlerden mezun olanların sayısının artışı görülmektedir. $\mathrm{Bu}$ artsşa rağmen ulusal ve uluslararası ekonomideki resesyonlar, işgücüne katılımı sağlayabilecek kamu ve özel sektör imkânlarının olmaması ve istihdam süreçlerindeki bilgi akışı problemleri, işsizlik sorununu ortaya çıkarmaktadır (Çakır ve Kellevezir, 2020, s. 3). Belirtilen makro sorunların yanı sıra öğrenim gören veya yeni mezun olan gençlerin işgücü niteliğinde de problemler olduğu söylenebilmektedir. Bu sorunun temel sebebi, eğitim sistemindeki uygulamaya dayalı ve saha tecrübesi kazanılabilecek eğitimlerin eksikliği ile oluşan "teori ve pratik arasındaki boşluk" durumudur. Bu yapıya sahip sistemlerde öğrenim gören gençlerin sahip olduğu nitelikler ile işgücü piyasasının beklentileri arasındaki farklılaşma ise genç işsizliği sorununu belirgin hale getirmektedir (Taş ve Bilen, 2014, s. 64; Hwang, 2016, s. 2). Türkiye'de 2019-2020 eğitim ve öğretim yllında üniversitelerde toplamda 7.940.133 öğrenci öğrenim görmüştür (Yükseköğretim Bilgi Yönetim Sistemi, 2020). Son 11 yllda üniversite mezunu oranı $\% 5,5$ 'ten $\% 13,9$ 'a yükselirken, işsizlik oranının son 11 yıl içerisinde $\% 10$ 'dan $\% 13,7$ ye çıktığ1 ve gençler arasında işsizlik oranının da 2019 yllında \%25,4 olduğu belirlenmiştir (Türkiye İstatistik Kurumu [TÜIKK], 2019). Bu çelişki, yalnızca ülke istatistiklerini değil gençlerin sosyal, ekonomik ve en önemlisi psikolojik durumlarını da etkilemektedir (Adak, 2010, s. 106). Eğitim yaşamı süresince gerek bireysel gerek ailesel çabalarla öğrenim gören mezunların işgücüne katılım ile ilgili beklentilerinin karşılanamaması, birçok soruna sebebiyet vermektedir (Taş ve Bilen, 2014, s. 61). İşsizlik sürecinin sosyal sonuçlarına örnek olarak işsizlik sebebiyle etiketlenme, ayrımcılık ve toplumdan izole olma; ekonomik sonuçlarına örnek olarak gelirin düşmesi, geçimi sağlamakta zorlanma ve temel ihtiyaçları karşılayamama durumunun getirdiği barınma, beslenme gibi sorunlar; psikolojik sonuçlara örnek olarak ise stresin artması, kaygı bozukluğu, depresyon ve umutsuzluk verilebilir.

Sosyal hizmet; hiçbir ayrım gözetmeksizin, sosyal yaşamında dezavantaj yaratan ve sorun olarak algıladığı herhangi bir özelliğe ve duruma sahip olan bireylere yardım etme temelli bir meslektir. Mikro, mezzo ve makro düzeyde müdahalelerle birey refahını artırmayı amaçlayan bu meslek, üniversitelerin akreditasyonlu sosyal hizmet lisans programlarında eğitilen meslek elemanlarıla uygulanmaktadır. Mesleğin akademik alandaki tarihi dünya çapında 19. yüzyılın sonlarına dayanırken, ülkemizde 1961'de Sosyal Hizmetler Akademisi ile ilk kez sosyal hizmet eğitimi başlamıştır. Son yıllarda ülkemizdeki üniversitelerin sayısının artmasıly birlikte, 2020 yll itibariyle 55 üniversitede sosyal hizmet lisans bölümü bulunmaktadır (Yükseköğretim Program Atlası [YÖK Atlas], 2020). Ayrıca açı öğretim fakültesi bulunan üniversitelerin sosyal hizmet bölümünün hem ön lisans hem de lisans programlarına öğrenci kabul etmesi, "Sağlıkta Lisans Tamamlama" uygulamasıyla diğer bölümlerden sosyal hizmet bölümüne geçilebilmesi ve "Sosyal Çalışma Görevlisi” tanımıyla yine diğer bölümlerin sosyal çalışmacı kadrolarına yerleşebilmeleri nedeniyle hem sosyal hizmet öğrencilerinin geleceklerine dair motivasyonları düşmekte hem de sosyal çalısmacıların işsizlik süreci uzamaktadır. Buna göre TÜİK'in 2018'de yayınladığ1 "Yüksekokul ve Fakülte Mezunlarının En Son Mezun Oldukları Alana Dair İşgücü Durumları" verilerinde yer alan sosyal hizmetler alanının \%24,3 ile en yüksek işsizlik oranına sahip olması, bahsedilen uygulamaların olumsuz sonuçlarını kanıtlar niteliktedir. Çalışma alanı dezavantajlı gruplar olan sosyal çalışmacılar, müracaatçı profiline uyan işsiz bireylere müdahale etmeleri gerekmekte fakat mevcut sistem ve uygulamalardan dolayı mesleki anlamda kendileri dezavantajlı duruma düşürülmektedir. 


\section{Yöntem}

Çalışmanın bu bölümünde araştırma modeline, çalışma grubuna, veri toplama aracı ve verilerin analizine detaylı bir şekilde yer verilmiştir. Bu çalısmanın amacı, yeni mezun sosyal çalışmacıların işsizlik kavramılla ilgili belirttikleri metaforları analiz etmektir. Bu amaçla aşağıdaki sorulara cevap aranmıstır:

1. Yeni mezun sosyal çalışmacıların işsizlik kavramılla ilgili belirttikleri metaforlar nelerdir?

2. Belirtilen metaforlar ortak özellikleri açısından hangi kavramsal kategoriler altında toplanmaktadır?

\section{Araştırmanın Modeli}

Son yıllarda işsizlik oranı en yüksek alanlardan biri olan sosyal hizmet bölümünden yeni mezun olmuş sosyal çalışmacıların işsizliğe ilişkin ifadelerinin incelenmesini amaçlayan bu çalışma, nitel araştırma modellerinden fenomenoloji (olgu bilim) modeli esas alınarak yapılandırılmıştır. Bu çalışmada kullanılan form ile yeni mezun sosyal çalışmacıların işsizlik kavramına yönelik metaforları belirlenmek istenmiştir, metafor araştırmalarında en uygun desen ise fenomenoloji (olgu bilim) desenidir (Ekici ve Akdeniz, 2018, s. 29).

Fenomenoloji, alg1 veya deneyimin temel yapılarını açıklama bilimidir. Ne deneyimin konusuna ne de deneyim nesnesine odaklanır, odaklandığı tek durum "varlık ve bilincin buluşma noktası" dır. Fenomenolojinin ilkesi, yaşanan bir deneyimin temelde ne olduğunun bireydeki içsel tezahürünü açıkça anlamaktır (Ivan, 2019, s. 4). Fenomenoloji modeli özellikle bireylerin deneyimlerini ve alg1larını kendi bakış açılarını ön plana çıkararak kavramsallaştırmada kullanılmaktadır. Bu nedenle belirli bir konuda hâlihazırda gündemde olan yapısal ve normatif varsayımları tartışmada da etkili olabilmektedir (Lester, 1999 , s. 1). Kısaca bu desenin kullanıldığı araştırmalarda bulgulara, katılımcıların yorumları ve anlamlandırmalarını nasıl ilettiği incelenmektedir.

\section{Örneklem Seçimi}

Araştırmanın örneklemini-2018-2019 ve 2019-2020 eğitim ve öğretim yıllarında üniversitelerin sosyal hizmet lisans bölümlerinden mezun olmuş bireyler oluşturmaktadır. Örneklem belirlenmesinde, olasıllklı olmayan örnekleme türlerinden kartopu örnekleme yöntemi kullanılmıştır. Kartopu örnekleme tekniği, araştırmanın uygulanacağı çalışma grubuna ilişkin gerekli özelliklere sahip ve veri elde edilebilecek kişilere ulaşmak için görüşülen katılımcıların aracılığını kullanmak olarak tanımlanabilmektedir (Doğan ve Ersoy, 2020, s. 1825). Bu araştırmada kartopu örnekleme tekniğinin seçilme amac1, araştırmanın çalışma grubuna ulaşımın güç olmasıdır. Kartopu örnekleme yöntemi, katılımcılara ulaşımı kolaylaştırmıştır. Buna göre araştırma için gerekli özellikleri taşıyan bireylere ulaşabilecek ilk birim olarak iki yeni mezun sosyal çalışmacı belirlenmiştir. İlk birimin belirlenmesinde ise olasılıklı olmayan örnekleme türlerinden kolayda örnekleme yöntemi kullanılmıştır. Kolayda örnekleme yöntemi, çalışmaya uygun ve araştırmacı için en kolay ulaşılabilir kişilerin öncelikle araştırmaya dahil edilmesi olarak ifade edilebilmektedir (Coşkun vd., 2017, s. 132). Kolayda örnekleme yöntemiyle seçilen iki kişinin, ulaşlabilecek diğer yeni mezun sosyal çalışmacilarla temas kurması ile de çalışma grubu kartopu şeklinde büyümüştür. Elde edilen 85 veri incelendikten sonra eksik doldurulmuş 5 adet formun varlığ tespit edilmiş ve bunlar araştırma kapsamına alınmamışır.

Tam ve amacına uygun form dolduran 80 birey (sosyal çalışmacı) örnekleme alınmıştır. Bunların 49'unu kadınlar, 31'ini erkekler oluşturmaktadır. Katılımcıların yaşlarına bakıldığında; 3 kişsinin 21, 32 kişinin 22, 23 kişinin 23, 14 kişinin 24, 4 kişinin 25, 3 kişinin 26 ve 1 kişinin de 27 yaşında olduğu görülmektedir. Ek olarak çalışmaya 2018-2019 eğitim ve öğretim yllından mezun olan 29, 2019-2020 eğitim ve öğretim yllından mezun olan ise 51 kişi katılımışıı. Ayrıca bu çalışmaya katılan yeni mezun sosyal çalışmacıların 64'ü çalışmazken 16'sı çalışmaktadır (bkz. Tablo 1.) 
Tablo 1. Katulimalar Hak.kinda Bilgi

\begin{tabular}{|c|c|c|c|}
\hline Demografik Özellik & $\begin{array}{c}\text { Demografik Özellik } \\
\text { Kategorisi }\end{array}$ & $\bar{f}$ & $\%$ \\
\hline \multirow{2}{*}{ Cinsiyet } & Kadin & 49 & 61,25 \\
\hline & Erkek & 31 & 38,75 \\
\hline \multirow{7}{*}{ Yaş } & 21 & 3 & 3,75 \\
\hline & 22 & 32 & 40 \\
\hline & 23 & 23 & 28,75 \\
\hline & 24 & 14 & 17,5 \\
\hline & 25 & 4 & 5 \\
\hline & 26 & 3 & 3,75 \\
\hline & 27 & 1 & 1,25 \\
\hline \multirow{2}{*}{ Mezuniyet Y1lı } & $2018-2019$ & 29 & 36,25 \\
\hline & $2019-2020$ & 51 & 63,75 \\
\hline \multirow{2}{*}{ Çalışma Durumu } & Çalışan & 16 & 20 \\
\hline & Çalışmayan & 64 & 80 \\
\hline \multicolumn{2}{|c|}{ Toplam } & 80 & 100 \\
\hline
\end{tabular}

Veri Toplama Aracı

$\mathrm{Bu}$ araştırma verilerinin toplanması süreci, 2020 yılının Ekim ve Kasım aylarını kapsamaktadır. Katılımcılara dijital olarak oluşturulan formun URL adresi gönderilerek ulaşılmışır. Araştırmanın veri toplama aracı olarak araştırmacılar tarafından hazırlanmış olan iki bölümlü bir form kullanılmıştır. Formun ilk bölümünde katılımcilardan yaş, cinsiyet, mezuniyet yılları ve çalıșma durumları bilgilerini belirtmeleri istenmiştir. Formun ikinci bölümünde ise "İşsizliği bir şeye benzetecek olsanız neye benzetirdiniz? Neden?" sorusuna yönelik cümleyi doldurmalarına ilişkin bir yönerge verilmiştir. Ardından "İssizilik gibidir, çünkü ....................... . " cümlesi ile form sonlandırlmıştır. Bu cümledeki "gibidir/benzer" kelimeleriyle yeni mezun sosyal çalışmacıların işsizlik kavramına ilişkin algılarını hangi metafor aracılığıyla yansıttıkları belirlenirken, "çünkü" ile başlayan kısım ile de metaforlarını benzetme yönlerinin ortaya konulması hedeflenmiştir. Yıldırım ve Şimşek'e göre de (2013, s. 70), metaforun belirtilmesinden sonra "niçin" veya "neden" soruları sorulmalıdır. Böylece hem bireyler kullandıkları metaforların betimsel ve görsel gücünü açığa çıkarabilecek, hem de araştırmacılar katılımcıların metaforu neye dayanarak kullandığını belirleyebilecektir (Çetintaş ve Avcu, 2017, s. 81).

\section{Verilerin Analizi}

Araştırma verileri içerik analizi yöntemi kullanılarak analiz edilmiştir. Verilerin analizi sırasıyla eleme, adlandırma, kategori geliştirme, geçerlik ve güvenirliğin sağlanması, elde edilen metaforların frekanslarının hesaplanması ve yorumlanması aşamalarından oluşmaktadır. Bu aşamalar aşağıda gösterilmektedir:

- Katılımcılar öncelikle "S1, S2, S3..." şeklinde adlandırılarak listelenmiştir.

- Yeni mezun sosyal çalışmacıların belirttiği ifadeler doğrultusunda metaforları ve gerekçeleri birlikte değerlendirilerek kategoriler geliştirilmiştir.

- Çalışmanın geçerlik ve güvenirliğini sağlama amacı doğrultusunda uygulamalar gerçekleştirilmiştir. Bu çalışmada, yapılan araştırmanın tüm adımları detaylı bir şekilde açıklanarak çalışmanın geçerliği sağlanmaya çalışılmıştır. Çalışmanın güvenirliği ise araştırmacılar tarafindan belirlenen kodlar ve kategorilerden bağımsız olarak, verilerin bilimsel araştırma ve bilim etiği dersi veren alanında uzman öğretim üyesine danışılması ile sağlanmaya çalışılmıstır. Öğretim üyesinin görüşleri ile araştırmacılarınkiler arasındaki tutarlılık ve metaforların belirlenen kategorilere uygunluğu incelenmiştir. Bu doğrultuda Miles ve Huberman' in (1994) geliştirdiği “uyuşum yüzdesi formülü” göz önünde bulundurularak hesaplama yapılmıştır. "[Görüş Birliği/ (Görüş Ayrllığ1+Görüş Birliği) x 100]" içeriğinde olan bu formül sonucu güvenirlik \%95 olarak hesaplanmiştır.

\section{Bulgular ve Tartışma}

Çalışmanın bu bölümünde, yeni mezun sosyal çalışmacıların işsizlik kavramına yönelik oluşturdukları metaforlar ve bu metaforlanın gruplanması sonucu oluşturulan kategoriler tablolar halinde gösterilmiştir. İşsizlik kavramına yönelik olarak katılan 80 yeni mezun sosyal çalışmacı toplamda 58 metafor geliştirmiştir. Bu metaforlar "Doğal Afet/Oluşum" (f=16), "Duygu Yansıması" ( $\mathrm{f}=16)$, "Mekan Tasviri" (f=14), 
“Dezavantaj Durumu” (f=13), "İşlev Bozukluğu Yaratan Durum” (f=12) ve "Nesne” (f=9) olmak üzere 6 kategori altında toplanmıştır.

Tablo 2. "İssiz̨lik" Kavramma Ilişkin Yeni Mezun Sosyal Calısmacular Tarafindan Geliștirilen Metaforlarn Dağılımı

\begin{tabular}{|c|c|c|c|c|c|}
\hline Sira & Metafor Ad1 & $\mathbf{F}$ & S1ra & Metafor Ad1 & f \\
\hline 1 & Boşluk & 5 & 30 & Kalitesiz kulaklık & 1 \\
\hline 2 & Hastalık & 5 & 31 & Karadelik & 1 \\
\hline 3 & Kuyu & 4 & 32 & Karanlık & 1 \\
\hline 4 & Çaresizlik & 3 & 33 & Kartopu & 1 \\
\hline 5 & Bataklık & 2 & 34 & Kasvetli hava & 1 \\
\hline 6 & Çile çekmek & 2 & 35 & Kenar süsü & 1 \\
\hline 7 & Elma kurdu & 2 & 36 & Kendi kitabından bir sayfa & 1 \\
\hline 8 & Girdap & 2 & 37 & Kulpu olmayan kap1 & 1 \\
\hline 9 & Kabus & 2 & 38 & Küflenmiş ekmek & 1 \\
\hline 10 & Kasırga & 2 & 39 & Köy & 1 \\
\hline 11 & Sabretmek & 2 & 40 & Labirent & 1 \\
\hline 12 & Tiyatro sahnesi & 2 & 41 & Macera & 1 \\
\hline 13 & Yoksulluk & 2 & 42 & Meyve vermeyen ağaç & 1 \\
\hline 14 & Anlam arayışı & 1 & 43 & Platon'un mağara alegorisi & 1 \\
\hline 15 & Balyoz & 1 & 44 & Rezil olmak & 1 \\
\hline 16 & Bozuk süt & 1 & 45 & Sel & 1 \\
\hline 17 & Bulmaca & 1 & 46 & Solmak & 1 \\
\hline 18 & Buruk tat & 1 & 47 & Sonbaharda savrulan yaprak & 1 \\
\hline 19 & Canavar & 1 & 48 & Sonu görünmeyen tünel & 1 \\
\hline 20 & Çöl & 1 & 49 & Sosyal hizmet & 1 \\
\hline 21 & Değersiz hissetmek & 1 & 50 & Test & 1 \\
\hline 22 & Dikenli yol & 1 & 51 & Tükenmiş kalem & 1 \\
\hline 23 & Ektiğini biçemeyen çiftçi & 1 & 52 & Okul & 1 \\
\hline 24 & Evde kalmak & 1 & 53 & Öksüzlük & 1 \\
\hline 25 & Guguklu saat & 1 & 54 & Ölüm & 1 \\
\hline 26 & Hayal kırıklı̆̆1 & 1 & 55 & Uzun yolculuk sonrası dinlenme & 1 \\
\hline 27 & Hirs & 1 & 56 & Yapboz & 1 \\
\hline 28 & Issız yolda kalmış araba & 1 & 57 & Yas & 1 \\
\hline 29 & Kafası kesilmiş ve ölmemiş tavuk olmak & 1 & 58 & Yorgunluk & 1 \\
\hline
\end{tabular}

Tablo 2 incelendiğinde; yeni mezun sosyal çalısmacıların "işsizlik" kavramına yönelik olarak toplam 58 çeşit metafor belirttikleri ve bunun için toplam 80 görüş ifade ettikleri görülmektedir. Katıllımcıların işsizlik kavramıyla ilgili en fazla belirttikleri ilk dört metafor; Boşluk, Hastalık, Kuyu, Çaresizlik olarak sıralanmıştır. İlk dört ve toplam 58 metafor kapsamında değerlendirme yapıldığında; yeni mezun sosyal çalısmacıların işsizlik kavramına yönelik olarak oldukça fazla sayıda olumsuz görüş belirttikleri tespit edilmiştir. Diğer taraftan anlam arayışı, uzun yolculuk sonrası dinlenme, sabretmek, yapboz, okul, kasvetli hava, hırs gibi metaforların işsizliğin yalnızca olumsuz yönlerine odaklanmamış olduğu belirlenmiştir. Toplam 13 metaforun 5 ile 2 arasında tekrar edilme sıklı̆ı olduğu belirlenirken, geriye kalan toplam 45 metaforun ise birer kez tekrar edildiği belirlenmiştir. Bu bulgudan yola çıkarak işsizlik kavramı ile ilgili yeni mezun sosyal çalışmacıların algılarında genel olarak kişisel farklılıkların ortaya çıktığı söylenebilmektedir. Metaforlar, ifade edilişi ve benzetme yönlerinin kapsamına göre altı farklı başlıkta kategorilendirilmiştir.

Tablo 3. Yeni Mę̧un Sosyal Çalısmacılarn “Doğal Afet/Oluşum” Kategorisindeki Metaforlarn

\begin{tabular}{clll}
\hline Kategori & $\boldsymbol{N}$ & Metafor & \\
\hline & & Kuyu & 4 \\
& & Bataklik \\
& & Kara delik & 2 \\
& & Kasirga & 2 \\
Doğal Afet/Oluşum & 16 & Çöl & 1 \\
& & Girdap & 1 \\
& Karanlik & 1 \\
& Kartopu & 1 \\
& Kasvetli hava & 1 \\
\end{tabular}


Tablo 3'te yer alan doğal afet/oluşum olarak işsizlik, duygu yansıması kategorisi ile birlikte en çok yükleme yapılan kategoridir. Bu kategoriyi oluşturan metaforlar 16 yeni mezun sosyal çalışmacı tarafindan 10 kod şeklinde ifade edilmiştir. Toplam metaforun \%27,58'ini oluşturmaktadır. Doğal afet/oluşum kategorisine kaynak olan metaforlar şunlardır; kuyu, bataklık, karadelik, kasırga, çöl, girdap, karanlık, kartopu, kasvetli hava, sel. Doğal afet/oluşum kategorisinde yer alan kodlara ilişkin örnek katılımc1 ifadeleri aşağıda sunulmuştur:

Kuyu; "İşsizlik derin bir kuyu gibidir, çünkü ne çıkışı görebilirsin ne de görebilmek için ne kadar yol alman gerektiğini bilirsin.” (S5) (S14)

Bataklık; "İşsizlik bataklık gibidir, çünkü çıkmak için çırpınırsın ve her gün daha da derine batarsın."

Karadelik; "İşsizlik karadelik gibidir, çünkü her umudu içine çekiyor.” (S38)

Kasırga; “İşsizlik kasırga gibidir, çünkü öncesi sessizlik sonrası felaket.” (S29)

Çöl; “İşsizlik çöl gibidir, çünkü işin yokken hayatındaki hiçbir şey yeşermez.” (S63)

Girdap; "İşsizlik girdap gibidir, çünkü çaresizce çırpınıp durursun ve çıkamazsın.” (S79)

Karanlık; “İşsizlik karanlık gibidir, çünkü önünü göremezsin.”(S52)

Kartopu; "İşsizlik kartopu gibidir, çünkü durumlar arasında neden-sonuç ilişkisi olacak şekilde büyüyen ve birbirini etkileyen durumlar zinciri haline gelir.” (S11)

Kasvetli hava; "İşsizlik kasvetli hava gibidir, çünkü can sıkar ama yine de arkasından güneş geleceğini ümit edersin." (S67)

Sel; “İşsizlik sel gibidir, çünkü sağlam olan her şeyi beraberinde belirsizliğe sürükler.” (S2)

Örnek metaforlar ve gerekçelerinde de görüldüğü gibi, bu kategorinin oluşmasına kaynak olan bireylerin işsizlik algısı diş etkenlerle özdeşleşmiştir. Yapıc1 ve Nalinci’ nin (2020, s. 490) çalışmasında da benzer şekilde "doğa olayı" kategorisindeki metaforların gerekçesinde bireylerin süreçte kendini yetersiz ve güçsüz hissettiği belirlenmiştir. Bu çalışmada, bu kategori çerçevesinde işsizliğin var olan olumlu olguları da yok eden, bireyi çaresiz bırakan ve belirsizliğin hakim olduğu bir durum olarak algılandığı belirlenmiştir.

Tablo 4. Yeni Mezun Sosyal Calısmacularn "Duygu Yansiması” Kategorisindeki Metaforlar

\begin{tabular}{|c|c|c|c|}
\hline Kategori & $\boldsymbol{N}$ & Metafor & $f$ \\
\hline Duygu Yansiması & 16 & $\begin{array}{l}\text { Çaresizlik } \\
\text { Kabus } \\
\text { Sabretmek } \\
\text { Anlam Arayışı } \\
\text { Canavar } \\
\text { Hayal Kırıklı̆̆1 } \\
\text { Değersiz Hissetmek } \\
\text { Hırs } \\
\text { Macera } \\
\text { Rezil Olmak } \\
\text { Uzun Yolculuk Sonrası Dinlenme } \\
\text { Yorgunluk }\end{array}$ & $\begin{array}{l}3 \\
2 \\
2 \\
1 \\
1 \\
1 \\
1 \\
1 \\
1 \\
1 \\
1 \\
1\end{array}$ \\
\hline
\end{tabular}

Tablo 4.'te yer alan duygu yansıması kategorisi en çok yükleme yapılan iki kategoriden diğeridir ve toplam metaforun \%27,58'ini oluşturmaktadır. Bu kategoriyi oluşturan metaforlar 16 yeni mezun sosyal çalışmacı tarafından 12 kod şeklinde ifade edilmiştir. Duygu yansıması kategorisine kaynak olan metaforlar: çaresizlik, kabus, sabretmek, anlam arayışı, canavar, hayal kırıklı̆̆ı, değersiz hissetmek, hırs, macera, rezil olmak, uzun yolculuk sonrası dinlenme, yorgunluk şeklindedir. Duygu yansıması kategorisinde yer alan kodlara ilişkin örnek katılımcı ifadeleri aşağıda sunulmuştur:

Çaresizlik; "İşsizlik öğrenilmiş çaresizlik gibidir, çünkü okurken bu sonun seni bulacağını bilsen de öğrenimine devam edersin.” (S21)

Kabus; "İşsizlik kâbus gibidir, çünkü uyanmak istersin.” (S12)

Sabretmek; "İşsizlik sabretmek gibidir, çünkü iş hayatına adım atana dek geçmen gereken bir süreçtir ve sabir gerektirir." (S37) 
Anlam arayışı; "İşsizlik anlam arayışı gibidir, çünkü insanın kendini, yeterliliklerini ve varoluşunu sorgulamaya daha çok vakti olmaktadır.” (S8)

Canavar; "İşsizlik canavar gibidir, çünkü korkusu ile içten içe yiyip bitiren, can sıkıcı bir şeydir.” (S3)

Hayal kırıklı̆ğ; "İsssizlik hayal kırıklı̆ı gibidir, çünkü onca sene okur ve emek verirsin ama sonuçta elinde hiçbir şey olmaz" (S73)

Değersiz hissetmek; "İşsizlik değersiz hissetmek gibidir, çünkü paranız yoksa değersiz kabul edilirsiniz."(S55)

Hırs; "İşsizlik hırs gibidir, çünkü düşsen de amacına ulaşmak için hep yerinden daha güçlü kalkman için sebepler üretmen gerekir.” (S43)

Macera; "İşizlik macera gibidir, çünkü başımızdan geçen ilginç, belirsiz bir serüvendir.” (S19)

Rezil olmak; "İşsizlik rezil olmak gibidir, çünkü dost düşman herkesin diline düşersin ve sürekli sorgulanirsin." (S23)

Uzun yolculuk sonrası dinlenme; "İsssizlik uzun yolculuk sonunda dinlenmek gibidir, çünkü tekrar motive olmak zaman alır ama mutlaka ayağa kalkacağını bilirsin.” (S17)

Yorgunluk; "İşsizlik yorgunluk gibidir, çünkü kişi birçok açıdan harekete geçecek gücü bulamamaktır." (S80)

Duygu yansıması olarak işsizlik kategorisindeki metaforların gerekçelerine bakıldığında olumsuz duyguların hakim olduğu görülmektedir. Sabretmek, anlam arayışı, hırs ve uzun yolculuk sonrası dinlenme kodlarının gerekçelerine bakıldığında işsizliğin yalnızca olumsuz yönlerine odaklanılmamış olduğu görülmektedir. Bu gerekçelerde işsizliğin bir sonuç değil süreç olduğu anlayışı hakimdir. Bu durum Hammarström ve Janlert'ın (2002, s. 628) boylamsal çalışmasının bulgularından biriyle açılanabilmektedir. Buna göre; işsizlik dönemi uzadıkça bireylerin mental sağlıkları, duyguları da bu durumdan olumsuz etkilenmektedir (Kıcır, 2017, s. 54). Çalışma grubunun yeni mezun bireylerden oluştuğu göz önünde bulundurulduğunda işsizliğin "yerinden daha güçlü kalkman için sebepler üretmen gereken" veya "kendini, yeterliliklerini ve varoluşunu sorgulamaya daha çok vakti olmasını sağlayan" bir süreç olarak belirtilmesinin bu bulguyla ilişkilendirilebilmesi mümkündür

Tablo 5. Yeni Mezun Sosyal Callsmaclarm "Mekan Tasviri" Kategorisindeki Metaforlar

\begin{tabular}{|c|c|c|c|}
\hline Kategori & 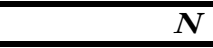 & Metafor & $f$ \\
\hline Mekan Tasviri & 14 & $\begin{array}{l}\text { Boşluk } \\
\text { Tiyatro sahnesi } \\
\text { Dikenli yol } \\
\text { Issız yolda kalmış araba } \\
\text { Köy } \\
\text { Labirent } \\
\text { Plato'nun mağara alegorisi } \\
\text { Sonu görünmeyen tünel } \\
\text { Okul }\end{array}$ & $\begin{array}{l}5 \\
2 \\
1 \\
1 \\
1 \\
1 \\
1 \\
1 \\
1\end{array}$ \\
\hline
\end{tabular}

Tablo 5'te yer alan mekan tasviri kategorisi 14 yeni mezun sosyal çalışmacı tarafından ifade edilmiş 9 kodun belirlenmesiyle oluşturulmuștur. Bu kategori, toplam metaforun \%24,13'sını oluşturmaktadır. Mekan tasviri kategorisini oluşturan metaforların sırası şöyledir: boşluk, tiyatro sahnesi, dikenli yol, 1ssız yolda kalmış araba, köy, labirent, Plato'nun mağara alegorisi, sonu görünmeyen tünel, okul. İfade edilen kodlara ilişkin örnek katılımcı ifadeleri aşağıda belirtilmiştir:

Boşluk; “İşsizlik Türkiye'de koca bir boşluk gibidir, çünkü uğraşın yoktur ve bomboşsundur.” (S48)

Tiyatro sahnesi; "İşsizlik sıkıcı bir tiyatro oyunu gibidir, çünkü bir süreliğine hayatın akışından kurtarır ve vakit geçmek bilmez." (S54)

Dikenli yol; “İşsizlik dikenli bir yol gibidir, çünkü canını acıta acıta o yolda yürürsün.” (S71)

Issız yolda kalmış araba; "İşsizlik ıssız bir yolda kalmış araba gibidir, çünkü birinin gelip gelmeyeceğini bilmezsiniz ve giderek umutlarınız azalır.” (S6) 
Köy; "İşsizlik yaz tatilinde internet ve yaşıt olmayan köye gitmek gibidir, çünkü sıkıntıdan bunalır bir an önce şehirdeki evine dönmek istersin ama bir yandan kafa dinleme firsatın da vardır.” (S50)

Labirent; "İşsizlik labirent gibidir, çünkü karmaşıktır ve çıkamadıkça çaresiz hissedersin, çok zor bir durumdur." (S24)

Plato'nun mağara alegorisi; “İşsizlik Plato’nun mağara alegorisi gibidir. Çünkü işsizliği bir karanlı̆̆a benzetirsek, karanlıktan aydınlığa ulaşabilenler kendi sınırlarını fark etme konusunda cesaretlenebilecek kimseler olacaktır ve bir daha oraya dönmek istemeyeceklerdir. O cesaretle 1şı̆̆a (gerçeğe) dönenler hayatın gerçek anlamını ve doğruyu görebilenler olacaktır.” (S18)

Sonu görünmeyen tünel; "İşsizlik sonu görünmeyen bir tünel gibidir, çünkü ne kadar zaman geçince 1şı̆̆a ulaşacağını bilemezsin.” (S31)

Okul; "İşsizlik okul gibidir, çünkü hayatı öğretir ve ona hazırlar.” (S60)

Katılımcıların mekân tasviri kategorisinde ifade ettikleri kodlar ve gerekçelerine bakıldı̆̆ında kendilerini zorlayan ve hatta çaresiz bırakan alanlara vurgu yaptıkları belirlenmiştir. Mekan tasviri kategorisindeki köy kodundaki "kafa dinleme fırsatı" ve okul kodundaki "hayatı öğretir ve ona hazırlar" ibareleri işsizlik döneminin öğretici ve dinlenme süreci olduğuna odaklanırken boşluk kodundaki "uğraşın yoktur ve bomboşsundur" ibaresi bu serbest dönem için ülkemizdeki etkinlik eksikliğine vurgu yapmaktadır. Akçay ve Alpoğlu (2020, s. 53) tarafından yapılan nitel çalışmaya göre; boşluk, sonu görünmeyen tünel, 1ssız yolda kalmış araba ve labirent metaforlarında belirtildiği gibi sosyal çalışmacıların işsizlik sürecinde en yoğun düşünceleri belirsizlik üzerinedir.

Tablo 6. Yeni Mezun Sosyal Calısmacularn "Dezavantaj Durumu” Kategorisindeki Metaforlarn

\begin{tabular}{|c|c|c|c|}
\hline Kategori & 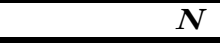 & Metafor & $f$ \\
\hline Dezavantaj Durumu & 13 & $\begin{array}{l}\text { Hastalık } \\
\text { Çile çekmek } \\
\text { Yoksulluk } \\
\text { Sosyal hizmet } \\
\text { Öksüzlük } \\
\text { Ölüm } \\
\text { Yas }\end{array}$ & $\begin{array}{l}5 \\
2 \\
2 \\
1 \\
1 \\
1 \\
1\end{array}$ \\
\hline
\end{tabular}

Tablo 6'da yer alan dezavantaj durumu kategorisi 13 yeni mezun sosyal çalışmacı tarafindan ifade edilmiş 7 kodun belirlenmesiyle oluşturulmuştur. Bu kategori, toplam metaforun \%22,41'sını oluşturmaktadır. Dezavantaj durumu kategorisini oluşturan metaforlar: hastalık, çile çekmek, yoksulluk, sosyal hizmet, öksüzlük, ölüm ve yas olarak siralanabilmektedir. Dezavantaj durumu kategorisine ait kodlara ilişkin örnek katılımcı ifadeleri aşağıda sunulmuştur:

Hastalık; “İşsizlik hastalık gibidir, çünkü her geçen gün yakaladığı insanı köreltir.” (S30)

Çile çekmek; "İşsizlik çile çekmek gibidir çünkü hayatımı sınırlıyor ve sarf ettiğim onlarca emek birkaç saatlik bir sinavla her şeyi bitiriyor.” (S69)

Yoksulluk; “İşsizlik yoksulluk gibidir, çünkü kapitalist düzende parasız muhtaçsındır.” (S77) (S4)

Sosyal hizmet; "İsssizlik sosyal hizmet gibidir, çünkü ihtiyacın vardır ama kimse sana değer vermez.”

Öksüzlük; "İşsizlik öksüzlük gibidir, çünkü hayata karşı bir dayanağın veya sırtını yaslayabileceğin bir güvencen yoktur" (S57)

Ölüm; "İşsizlik ölüm gibidir, çünkü özellikle psikolojik açıdan ne kadar zorlu bir süreç olduğunu biliyorum.” (S22) (S41)

Yas; "İşsizlik yas gibidir, çünkü bir dönem olduğunu bilirsin ama acı hiç geçmeyecekmiş gibi gelir"

Dezavantaj durumu olarak işsizlik kategorisinin ifadelerine bakıldığında sosyal hizmetin alanına giren ve sosyal hizmet müdahalesi gerektiren dezavantajlı durumların gerekçelendirildiği görülmektedir. Ölüm, yas, öksüzlük ve hastalık kodlarının geri döndürülemez sorunlara yol açan olumsuz durumlar oluşu dikkat geçmektedir. Benzer şekilde, Keskin Demirer (2016, s. 814) tarafından yeni mezunların işsizliğe ilişkin 
görüşleri üzerine yapılan araştırmada da katılımcıların depresyona yönelik ifadelere yer verdiği belirlenmiştir.

Tablo 7. Yeni Mezun Sosyal Calssmaclarn "İ̧lev Bozukluğu Yaratan Durum” Kategorisindeki Metaforlarn

\begin{tabular}{lll}
\hline \multicolumn{1}{c}{ Kategori } & $\boldsymbol{N}$ & \multicolumn{1}{c}{ Metafor } \\
\hline & Elma kurdu & \multicolumn{1}{c}{} \\
& Bozuk süt & 1 \\
& Buruk tat & 1 \\
& Ektiğini biçemeyen çiftçi & 1 \\
İşlev Bozukluğu Yaratan & Evde kalmak & 1 \\
Durum & Kafası kesilmiş ve ölmemiş tavuk olmak & 1 \\
& Kulpu olmayan kapi & 1 \\
& Küflenmiş ekmek & 1 \\
& Meyve vermeyen ağaç & 1 \\
& Solmak & 1 \\
\hline
\end{tabular}

Tablo 7'de yer alan işlev bozukluğu yaratan durum olarak işsizlik kategorisi, 12 yeni mezun sosyal çalışmacı tarafından üretilmiş 11 kod ile oluşmuştur. İşlev bozukluğu kategorisi toplam metaforların \%20,68'ini içermektedir. Bu kodlar: elma kurdu, bozuk süt, buruk tat, ektiğini biçemeyen çiftçi, evde kalmak, kafası kesilmiş ve ölmemiş tavuk olmak, kulpu olmayan kapı, küflenmiş ekmek, meyve vermeyen ağaç, solmak, sonbaharda savrulan yaprak olarak sıralanabilmektedir. Kodlara ilişsin örnek ifadeler aşağıda mevcuttur:

EIma kurdu; "İşsizlik elma kurdu gibidir, çünkü yaşamak istersin ama içindeki kurt seni günden güne çürütür." (S15)

Bozuk süt; "İşsizlik buzdolabında yer olmadığı için dışarıda kalıp bozulan süt gibidir, çünkü içeri girebilecekken giremez ve çürümeye mahkumdur.” (49)

Buruk tat; "İşsizlik ağızda kalan buruk tat gibidir, çünkü burukluğunu geçirmek zordur ve yalnızca tatlı bir şey yersen yani iş bulabilirsen geçer." (S34)

Ektiğini biçemeyen çiftçi; "İşsizlik ektiğini biçemeyen çiftçi gibidir, çünkü emek verdiğin şeylerin karşıllı̆ııı dış sebeplerden dolayı alamazsın.” (S20) (S78)

Evde kalmak; "İsssizlik evde kalmak gibidir, çünkü herkes acınası bir tavırla "olsun, bulursun" der"

Kafası kesilmiş ve ölmemiş tavuk olmak; "İşsizlik kafası kesilmiş ama ölmemiş tavuğa benzer, çünkü ne yiyecek bir yemeği vardır ne de hareket edecek hali." (S76)

Küflenmiş ekmek; "İşsizlik küflenmiş ekmek gibidir, çünkü beklemekten usanır ve ister istemez çürümeye başlarsın.” (S62)

Kulpu olmayan kapı; "İsssizlik kulpu olmayan bir kap1 gibidir çünkü dışardan kapıyı ne kadar zorlasanız da içerden biri gelip kapıyı size açmadığı sürece sadece beklersiniz ve o kapı içerden sadece tanıdıklara açılır." (S72)

Meyve vermeyen ağaç; "İşsizlik bir türlü meyve vermeyen ağaç gibidir, çünkü meyvenin yetişmesi için gerekli suyu, güneşi ve topraktan mineralleri almasına rağmen meyve vermez." (S61)

Solmak; "İssizlik solmak gibidir, çünkü kendine olan inancını yitirdiğin çok zaman olmaktadır." (S10)

Sonbaharda savrulan yaprak; "İşsizlik sonbaharda savrulan yapraklar gibidir, çünkü işi olmayan insanın hayatı dengesizdir ve psikolojik olarak çökmüştür." (S33)

Belirtilen metaforlarda da görüldüğü üzere işsizlik, yaşamı engelleyen ve var olan yaşam fonksiyonlarını yok eden bir durum olarak görülmüştür. Bu görüşlere benzer şekilde Yılmaz ve arkadaşlarının (2004, s. 170) da çalışmalarında belirttiği üzere işsizlik sürecinde kendine güven, iş bulmaya dair ümit, cesaret gibi kişisel özelliklerin beraberinde yetenek, beceri, bilgi ve birikim gibi mesleki değerlerin de kaybı söz konusu olmakta ve problemler ağırlaşmaktadır. Sonucunda depresyona sebep olabilen bu döneme dair makro düzeyde koruyucu ve önleyici politikalar zorunlu hale gelmektedir (Yüksel, 2003, s. 35). 
Tablo 8. Yeni Mezun Sosyal Callşmacularn "Nesne” Kategorisindeki Metaforlar

\begin{tabular}{|c|c|c|c|}
\hline Kategori & 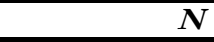 & Metafor & $f$ \\
\hline Nesne & 9 & $\begin{array}{l}\text { Balyoz } \\
\text { Bulmaca } \\
\text { Guguklu saat } \\
\text { Kalitesi kulaklık } \\
\text { Kenar süsü } \\
\text { Kendi kitabından bir sayfa } \\
\text { Test } \\
\text { Tükenmiş kalem } \\
\text { Yapboz }\end{array}$ & $\begin{array}{l}1 \\
1 \\
1 \\
1 \\
1 \\
1 \\
1 \\
1 \\
1\end{array}$ \\
\hline
\end{tabular}

Tablo 8'de yer alan nesne kategorisi en az yükleme yapılan kategori olarak belirlenmiştir. Bu kategoride işsizliğe dair belirtilmiş metaforlar 9 katılımcı tarafından her biri ayrı kodlanabilecek şekilde belirtilmiştir. Nesne olarak işsizliğe kaynaklık eden kodların sıralaması şu şekildedir: balyoz, bulmaca, guguklu saat, kalitesiz kulaklık, kenar süsü, kendi kitabından bir sayfa, test, tükenmiş kalem ve yapboz. Örnek metaforlar kodları ve gerekçeleri aşağıda verilmiştir:

Balyoz; "İssizlik balyoz gibidir, çünkü gururunu kırar, belini büker." (S16)

Bulmaca; "İşsizlik bulmaca gibidir, çünkü belirsizliklerle dolu, keşfedilmesi gereken bir durumdur." (S47)

Guguklu saat; "Işssizlik guguklu saat gibidir, her firsatta kendini sebep olduğu kötü çığlıklarla hatırlatır." (S70)

Kalitesiz kulaklık; "İ̧şizlik kalitesiz kulaklık gibidir, çünkü sen güzel müzikler dinlemeye çalıştıkça o c1zırdar." (S42)

Kenar süsü; "İşsizlik kenar süsü olmak gibidir, çünkü kendimi işe yaramaz ve enerjisiz hissetmeme neden oluyor." (S27)

Kendi kitabından bir sayfa; "İssizlik kendi yazdığın bir kitaptan bir sayfa gibidir, çünkü kahramanı sensindir ve yaşamına dair izlerle şekillenir." (S13)

Test; "İşsizlik test gibidir, çünkü kimi zaman sabrı kimi zaman da alternatifleri belirlemede insanı sinar." (S32)

Tükenmiş kalem; "İşsizlik tükenmiş kalem gibidir, çünkü tükenmez diye güvendiğin zamanların sonu gelir ve birden seni bitiriverir." (S74)

Yapboz; "İşsizlik yapboz gibidir, çünkü her an eksik parça bulunup resim tamamlanabilir." (S56)

Nesne olarak işsizlik kategorisindeki balyoz, guguklu saat, kalitesiz kulaklık ve tükenmiş kalem kodlarına bakıldığında işsizliğin, genel anlamda bazı temel fonksiyonlarından mahrum bıraktı̆̆ için artık değeri olmayan ve rahatsızlık oluşturan bir nesneye benzetilmesi ifade edilmiştir. Kendi kitabından bir sayfa ve test kodlarında dış dünyayla ilişkilendirmeden çok bireyin kendi kişiliği üzerindeki etkilere değinilmiştir. Bulmaca ve yapboz kodları sürecin belirsizliği ve kişinin yaşamında yarattığı boşluğun doldurulabileceği üzerinde durulmuştur.

Bulgular bölümünde belirtilen metaforların ana teması olumsuzluk üzerinedir. Benzer şekilde diğer bölümler üzerinde yapılan istihdam, işsizlik, gelecek kaygısı gibi çalışmalarda da gençlerin umutsuz, çaresiz hissettiği ve geleceklerini belirsiz olarak niteledikleri ortaya konulmuştur (Varışoğlu ve Kaşaveklioğlu, 2019, s. 486; Nalinci ve Yapıc1, 2020, s.490). Bu araştırmadaki katılımcıların yeni mezun oluşu ve \%80'inin işsiz olması metaforların bu denli olumsuz oluşun sebebiyet verebilirken, Tekin Tayfun ve Korkmaz (2016, s. 552) tarafından üniversite son sınıf öğrencilerinin katılımıyla yapılan işsizlik kaygısı araştırmasında da öğrencilerin iş bulma konusunda kaygıll oldukları analiz edilmiştir. Ek olarak Üstün ve arkadaşlarının (2014, s. 203) üniversite son sınıf öğrencileri üzerinde iş bulmaya ilişkin umutsuzluk düzeylerini belirlemeye yönelik yaptığı çalışmada ise çeşitli faktörlerin gençlerin umutsuzluk düzeylerini etkilediği üzerinde durulmuştur. Olumsuz ifadelerin altında yatan psikolojik ve sosyolojik baskılar gençlerin gelecek yaşamında problemlere sebep olabilmektedir. Genç bireylerin bu kaygı ve ümitsizliklerle geçen öğrencilik dönemleri sonrasında, yaşamlarını işsiz bir şekilde sürdürmelerinin daha derin psikolojik, sosyolojik ve fizyolojik sorunlara sebebiyet vermesi mümkündür. 


\section{Sonuç ve Öneriler}

Bu çalışmada yeni mezun sosyal çalışmacıların işsizliğe yönelik metaforik algıları incelenmiştir. Çalışmaya 80 yeni mezun sosyal çalışmacı katılmış ve işsizlik kavramı ile ilgili 58 farklı metafor belirtmiştir. Belirtilen metaforlar ve gerekçeleri altı kategori altında toplanmıştır. Çalışmada öncelikle "Yeni mezun sosyal çalışmacıların işsizlik kavramıyla ilgili belirttikleri metaforlar nelerdir?" sorusuna cevap aranmıştır. Bu doğrultuda gerçekleştirilen araştırmanın sonucunda, yeni mezun sosyal çalışmacıların işsizlik kavramını en sık boşluk, hastalık, kuyu, çaresizlik ve bataklık kavramlarıyla ifade ettikleri belirlenmiştir. Yeni mezun sosyal çalısmacıların işsizlik kavramı hakkında ifade ettiği kodlar ve gerekçeleri göz önünde bulundurulduğunda, baş edilmesi güç olan belirsiz bir süreci ve süreç içinde hissedilen umutsuzluğu niteledikleri görülmektedir.

Çalışmanın ikinci amacı ise "Belirtilen metaforlar ortak özellikleri açısından hangi kavramsal kategoriler altında toplanmaktadır?" sorusuna cevap bulmaktır. Bu amaca yönelik bulgular, araştırmaya katılan yeni mezun sosyal çalışmacılara ait metaforların; doğal afet/oluşum, duygu yansıması, mekan tasviri, dezavantaj durumu, işlev bozukluğu yaratan durum ve nesne olmak üzere altı kategori altında toplandığını göstermektedir. Katılımcıların doğal afet/oluşum kategorisi altında işsizliği "kuyu, bataklık, karadelik, kasırga, çöl, girdap, karanlık, kartopu, kasvetli hava, sel" metaforlarına benzettikleri görülmektedir. Araştırmada katılımcılar tarafindan en çok yükleme yapılan iki kategoriden biri olan doğal afet/oluşum kategorisi doğrultusunda, yeni mezun sosyal çalışmacıların işsizlik kavramını kişisel faktörlerden ziyade olumsuz etkilere sebep olan harici koşullar ile kodladığı bulgusuna ulaşılmıştır. En çok yükleme yapılan diğer kategori ise duygu yansıması kategorisidir. Yeni mezun sosyal çalışmacıların, duygu yansıması kategorisi alıındaki işsizlik kavramı metaforlarının "çaresizlik, kabus, sabretmek, anlam arayışı, canavar, hayal kırıklığı, değersiz hissetmek, hırs, macera, rezil olmak, uzun yolculuk sonrası dinlenme, yorgunluk" şeklinde üretildiği belirlenmiştir. Özellikle sabretmek, anlam arayışı, hırs ve uzun yolculuk sonrası dinlenme kodları göz önünde bulundurulduğunda, katılımcıların bu kategoride işsizliğin kaçınılmaz bir sonuç olmasından ziyade bir süreç olarak algıladığı ve dolayısıyla işsizliğin yalnızca olumsuz yönlerine vurgu yapmadı̆̆ı görülmektedir. Mekan tasviri kategorisi altında ise işsizlik kavramı, "boşluk, tiyatro sahnesi, dikenli yol, 1ssız yolda kalmış araba, köy, labirent, Plato' nun mağara alegorisi, sonu görünmeyen tünel, okul" metaforları ile ifade edilmiştir. Bu kategori incelendiğinde, yeni mezun sosyal çalışmacıların sosyal yaşamdan izole olmaya neden olan mekanları niteleyerek işsizlik kavramını tasvir ettiği belirlenmiştir. Dezavantaj durumu kategorisinde ise katılımcıların işsizlik kavramını "hastalık, çile çekmek, yoksulluk, sosyal hizmet, öksüzlük, ölüm, yas" metaforlarına benzettikleri görülmektedir. Kategori kapsamında belirtilen metaforlar ve gerekçelerinin psikolojik, sosyal, ekonomik ve fiziksel müdahaleler gerektiren durumlar olduğu bulgusuna varılmıştır. İşlev bozukluğu yaratan durum kategorisinde ifade edilen metaforlar "tavuk olmak, kulpu olmayan kapı, küflenmiş ekmek, meyve vermeyen ağaç, solmak, sonbaharda savrulan yaprak" olarak sıralanabilmektedir. Yeni mezun sosyal çalışmaciların metaforları doğrultusunda oluşan işlev bozukluğu yaratan durum kategorisinde işsizlik, yaşama ket vuran ve yaşamda gerekli olan fonksiyonların kaybına sebep olan bir kavram olarak karakterize edilmiştir. Son olarak yeni mezun sosyal çalışmacıların işsizliği nesne olarak nitelediği kategoride, "balyoz, bulmaca, guguklu saat, kalitesiz kulaklık, kenar süsü, kendi kitabından bir sayfa, test, tükenmiş kalem, yapboz" metaforları kullanılmıştır. Kategorinin içerdiği metaforlar ve gerekçeleri incelendiğinde eksik, varllğıyla rahatsız eden ve değersiz görülen nesnelerin işsizlik kavramını betimlemek için kullanıldığı görülmektedir.

$\mathrm{Bu}$ çalışmadan elde edilen bulgular doğrultusunda birtakım önerilerde bulunulabilmektedir. Bu çalışma araştırmaya katılan 80 yeni mezun sosyal çalışmacı ile sınırlıdır, gelecek çalışmalar için daha geniş çalışma grubuyla araştırma gerçekleştirilmesi önerilmektedir. Gençlerin iş bulma konusunda umutsuzluk düzeylerini etkileyen bireysel, çevresel ve makro faktörler belirlenerek bunlara yönelik müdahale planları oluşturulabilir. Sosyal çalışmacılara yönelik kamuda istihdam olanaklarının artırılması ve sosyal çalışmacı kadrolarına diğer branş mezunlarının atamaları ile ilgili düzenleme çalışmaları yapılabilir. Sosyal hizmet bölümü öğrencilerine lisans eğitimleri esnasında hem kamuda sosyal çalışmacı kadroları bulunan kurumları (Milli Eğitim Bakanlığı, Adalet Bakanlığı, Türk Silahlı Kuvvetleri vb.) hem de kamu dışındaki iş imkanları (sivil toplum kuruluşları, uluslararası organizasyonlar, özel sektör kuruluşları vb.) hakkında detaylı bilgi verilebilir. Gençlerin işsizlik sürecini bir kayıp olarak görmemeleri için bu sürece yönelik kişisel gelişim faaliyetleri artırılabilir. Yeni mezun bireyleri işe alırken tecrübe kriterinden dolayı olumsuz yargılara sahip iş verenler ile bu konudaki düşünce ve tutumlarını değiştirmeye yönelik çalışmalar yapılabilir. 


\section{Etik Beyan}

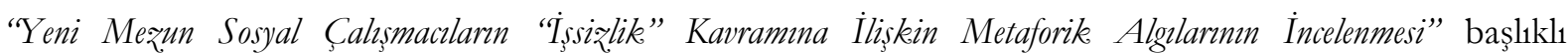
çalışmanın yazım sürecinde bilimsel kurallara, etik ve alıntı kurallarına uyulmuş; toplanan veriler üzerinde herhangi bir tahrifat yapılmamış ve bu çalışma herhangi başka bir akademik yayın ortamına değerlendirme için gönderilmemiştir. Bu araştırmanın verileri 01.01.2020 tarihinden önce toplandığı ve makalenin süreci 2020 yılında başladığından etik kurul kararı zorunluluğu taşımamaktadır.

\section{Kaynakça}

Adak, N. (2010). Sosyal bir problem olarak işsizlik ve sonuçları. Toplum ve Sosyal Hižmet, 21(2), 105-116.

Akçay, S. ve Alpoğlu, İ. E. (2020). Sosyal hizmet uzmanlarının işsizlik deneyimleri. Toplum ve Sosyal Hiæ̌met, 31 (1), $47-$ 69.

Coşkun, R., Altunışık, R. ve Yıldırım, E. (2017). Araştırma evreni ve örnekleme. Sosyal Bilimlerde Araştırma Yöntemleri: SPSS Uygulamal içinde (s. 139-158). Sakarya: Sakarya Kitabevi.

Çakır, Ö. ve Kellevezir, İ. (2020). Yükseköğretim mezunlarında işsizlik ve nitelik uyumsuzluğu olgusu: UNI-VERI araştırma sonuçları 1şı̆̆ında bir değerlendirme. Calışma İlişkileri Dergisi, 1(Özel Sayı), 1-17.

Çetintaş. E. ve Avcu, Y. E. (2017). Ortaöğretim öğrencilerinin robotik kavramına ilişkin metaforik algılarının incelenmesi. Route Educational and Social Science Journal, 4(8), 78-98.

Doğan, K. ve Ersoy, A. F. (2020). Öğrencilerin problemli internet kullanımının okul sosyal hizmeti bağlamında değerlendirilmesi: Nitel bir çalışma. Üçüncü Sektör Sosyal Ekonomi Dergisi, 55(3), 1822-1836. doi: 10.15659/3.sektor-sosyal-ekonomi.20.08.1392

Ekici, G. ve Akdeniz, H. (2018). Lise öğrencilerinin “ödev” kavramına ilişkin metaforik algılarının incelenmesi. Bayburt Ë̆itim Fakültesi Dergisi, 13(25), 26-37. doi: 10.14582/DUZGEF.1854

Hammarström, A., ve Janlert, U. (2002). Early unemployment can contribute to adult health problems: Results from a longitudinal study of school leavers. Journal of Epidemiology and Community Health, 56(8), 624-630. doi: 10.1136/jech.56.8.624

Hwang, Y. (2017). What is the cause of graduates' unemployment? Focus on individual concerns and perspectives. Journal of Educational Issues, 3(2), 1-10. doi: 10.5296/jei.v3i2.11378

Iş1k, V. (2016). Türkiye'de genç işsizliği ve genç nüfusta atalet. Emek, ve Toplum, 5(11), 130-145.

Ivan, K. (2019). The role of phenomenological research methodology in management research. Phenomenological Research Methodology Project Paper, Monarch Business School, Switzerland.

İrge, N. (2012). Enformasyon toplumu ve toplumsal değişim sürecinde sosyal medya. Akedeniz. Üniversitesi İletişim Fakültesi Dergisi, (17), 63-86.

Keskin Demirer, D. (2016). Yükseköğretimin emek piyasası'nda değersizleştirilmesi: yeni mezunların deneyimleri 1şığında tartışmalar ve çözüm arayışları. Calışma ve Toplum Dergisi, 2(49), 809-826.

Kıcır, B. (2010). Üniversite son simf ögrencilerinde işsizlik kaygısı: psikolojik etmenler açsından bir inceleme (Yüksek Lisans Tezi). Ankara Üniversitesi Sosyal Bilimler Enstitüsü, Ankara.

Lester S (1999). An introduction to phenomenological research. Taunton: Stan Lester Developments.

Nalinci, S. ve Yapıc1, M. (2020). Meslek yüksekokulu öğrencilerinin enflasyon ve işsizliğe ilişkin metaforları. Akademik Sosyal Arastırmalar Dergisi, 8(101), 481-492. doi: 10.29228/ASOS.40089

Taş, H. ve Bilen, M. (2015). Avrupa Birliği ve Türkiye'de genç işsizliği sorunu ve çözüm önerileri. Hak Işs Uluslararası Emek ve Toplum Dergisi, 3(6), 50-69.

Tekin Tayfun, A. N. ve Korkmaz A. (2016). Üniversite öğrencilerinde işsizlik kayg1sı: Süleyman Demirel Üniversitesi öğrencileri üzerinde bir araştırma. Mehmet Akif Ersoy Üniversitesi Sosyal Bilimler Enstitüsü Dergisi, 8(17), 534-558.

TÜİK, (2019, Mart). İşücü İstatistikleri [Haber Bülteni]. 16.11.2020 tarihinde https://www.tuik.gov.tr/ adresinden erişilmiştir.

TÜİK, (2019, Mart). İstatistiklerle Gençlik [Haber Bülteni]. 16.11.2020 tarihinde https://www.tuik.gov.tr/ adresinden erişilmiştir.

Üstün, G., Dedekoç, Ş., Kavalalı, T., Öztürk, F., Sapc1, Y. ve Can, S. (2014). Üniversite son sınıf öğrencilerinin iş bulmaya ilişkin umutsuzluk düzeylerinin incelenmesi. Amasya Üniversitesi Ë̆itim Fakültesi Dergisi, 3(2), 200-221.

Varışoğlu, B. ve Kaşaveklioğlu, G. (2019). Atanamayan öğretmen kavramına yönelik metaforlar. Sosyal Bilimler Arastirmalar Dergisi, 14(2), 473-490.

Yıldırım, A., ve Şimşek, H. (2013). Sosyal bilimlerde nitel araştırma yöntemleri. Ankara: Seçkin Yayıncılık.

Yılmaz, T., Fidan, F. ve Karataş, V. (2004). İşsizliğin sosyo-psikolojik sonuçları: sosyodemografik özelliklere göre bireylerin tutumları bir alan araştırması. Sosyal Siyaset Konferanslar, 48, 163-183.

YÖK Atlas, (2020). Sosyal Hizmet (Fakülte) Programı Bulunan Tüm Üniversiteler 17.11.2020 tarihinde https://yokatlas.yok.gov.tr/lisans-bolum.php?b=10193 adresinden erişilmiştir.

Yükseköğretim Bilgi Yönetim Sistemi, (2020). Öğrenim Düzeyine Göre Öğrenci Sayıs1: 2019-2020 Yükseköğretim İstatistikleri.16.11.2020 tarihinde https://istatistik.yok.gov.tr/ adresinden erişilmiştir.

Yüksel, İ. (2003). İşsizliğin psiko-sosyal sonuçlarının incelenmesi (Ankara Örneği). C.Ü. İktisadi ve İdari Bilimler Dergisi, $4(2), 21-38$. 


\section{EXTENDED ABSTRACT}

While unemployment continues to be a rapidly globalizing problem, the fact that the majority of those affected by this problem is young people also creates negative effects on individual dimensions. Social workers, whose field of work is disadvantaged groups are required to intervene in unemployed individuals who fit the client profile, but they are put in a professional disadvantage due to the current system and practices. The aim of this study is to examine and analyze the metaphors of recently graduated social workers which have the highest number of unemployed graduates in Turkey, regarding the concept of "unemployment". With the form used in this study, it was aimed to determine the metaphors of recently graduated social workers towards the concept of unemployment, and the most appropriate pattern in metaphor research is the phenomenology pattern (Ekici \& Akdeniz, 2018, p.29). As the data collection tool of the research, a two-part form prepared by the researchers was used. In the first part of the form, participants were asked to indicate their age, gender, years of graduation and employment status. In the second part of the form "Unemployment is like ................, because .............. " the sentence was asked to be filled. The research working group of the study consists of 80 individuals who graduated from the undergraduate social work departments of universities in 2018-2019 and 2019-2020 academic and training years. Snowball sampling method was used in the research working group. The research working group of this research consists of 80 forms filled completely and in accordance with its purpose. 49 of them are women and 31 of them are men. The ages of the participants: it is seen that 3 people are 21, 32 people are 22, 23 people are 23, 14 people are 24, 4 people are 25, 3 people are 26 and 1 person is 27 years old. In addition, 29 people who graduated from the 2018-2019 academic year and 51 people from the 2019-2020 academic year participated in the study. Also 64 of the recently graduated social workers who participated in this study are unemployed while 16 are working. A content analysis method is used to analyze the research data. The analysis of the data consists of the stages of screening, naming, category development, ensuring validity and reliability, calculating, and interpreting the frequencies of the obtained metaphors, respectively. 80 recently graduated social workers who participated in this research developed 58 metaphors in total. These metaphors' categories are "Natural Disaster/Occurrence" ( $f=16)$, "Reflection of Emotion" ( $\mathrm{f}=16)$, "Description of Space" ( $\mathrm{f}=14)$, "Disadvantage Situation" ( $\mathrm{f}=13)$, "Dysfunction Causing Situation" ( $\mathrm{f}=12)$ and "Object" $(\mathrm{f}=9)$. The metaphors that are the source of the first category "natural disaster/occurrence" categories' codes are as follows; well, swamp, black hole, hurricane, desert, swirl, darkness, viburnum, gloomy weather, flood. The unemployment perception of individuals, which is the source of the formation of this category, has been identified with external factors, and it has been determined that they feel inadequate and powerless in the process. The second category is the "reflection of emotion" category. The metaphors that make up this category were expressed by 16 recently graduated social workers in 12 codes. The metaphors that are the source of the emotion reflection category are: helplessness, nightmare, patience, search for meaning, monster, disappointment, feeling worthless, ambition, adventure, being disgraced, resting after a long journey, fatigue. Considering the reasons for the metaphors in the unemployment category as a reflection of emotion, it is seen that negative emotions prevail. According to the longitudinal study of Hammarstrom and Janlert (2002), the longer unemployment period affected the more negative mental health and emotions of individuals. Another category, "space description category", was created by determining 9 codes expressed by 14 recently graduated social workers. The order of the metaphors that make up the space description category are as follows: space, theater stage, thorny road, a car stuck on the desolate road, village, labyrinth, Plato's cave allegory, the invisible tunnel, school. According to the metaphors specified in this category, the most intense thoughts of social workers during the unemployment process are on uncertainty. The fourth category which is "the disadvantage" category was created by determining 7 codes expressed by 13 recently graduated social workers. The metaphors that make up the disadvantage category can be listed as illness, suffering, poverty, social work, orphanhood, death, and mourning. It can be exemplified by the expression, considering the expressions of the unemployment category as a disadvantage, it is seen that the disadvantaged situations that fall within the scope of social work and require social work intervention are justified. According to this category, unemployment is a negative and depressive situation that causes irreversible problems. The fifth category, "dysfunction", was formed with 11 codes produced by 12 recently graduated social workers. These codes can be listed as: apple worm, spoiled milk, bitter taste, farmer who cannot reap what he sows, being an old maid, being a beheaded but not dead chicken, a door without a handle, moldy bread, a tree that does not bear fruit, withering, and a leaf blown in autumn. As seen in the metaphors mentioned in this category, unemployment is seen as a situation that prevents life 
and destroys existing life functions. The metaphors of 9 participants constituted the last category, "object". The order of the codes that are the source of unemployment as objects are as follows: sledgehammer, puzzle, cuckoo clock, poor quality headphone, fringe, a page from own book, test, spent pen, and puzzle. In the findings of the research, it was determined that the perceptions of recently graduated social workers towards unemployment are expressed with quite negative metaphors. It is possible for young individuals to continue their lives unemployed after their student period with anxiety and hopelessness, causing psychological, sociological, and physiological problems. 